UDC 637.146.344

DOI https://doi.org/10.32838/2663-5941/2020.2-2/17

Helikh A.O.

Sumy National Agrarian

Dan Gao

Sumy National Agrarian

Zhenhua Duan

Hezhou University

\title{
OPTIMIZATION OF ULTRASOUND-ASSISTED ALKALINE EXTRACTION OF PUMPKIN SEED MEAL PROTEIN ISOLATE BY RESPONSE SURFACE METHODOLOGY ${ }^{1}$
}

As an alternative to animal proteins, pumpkin seed meal protein isolate (PSMPI) can be applied in food processing as dietary supplements and functional foods. The conventional extraction process of protein is alkaline solution and acid precipitation, which consumes a long time. Ultrasound method is an environmentally friendly technique, which can be used to improve the efficiency of protein extraction. In the present study, a method of ultrasound-assisted alkaline extraction (UAAE) of PSMPI was established.

Response surface methodology (RSM) was utilized to optimize the UAAE conditions (ultrasonic power, ultrasonic time and ratio of liquid to solid) by implementing a three-factor, three level Box-Behnken design. A quadratic polynomial equation was obtained by polynominal regression analysis of the experimental dada and appropriate statistical methods. The interaction effects of the independent variables on the extraction yield of PSMPI were illustrated by response surfaces and counter plots.

Besides, by solving the regression equation and analyzing the response surface contour plots, the determined optimal PSMPI extraction conditions were obtained, which was at ultrasonic power of $456 \mathrm{~W}$, ultrasonic time of $22 \mathrm{~min}$, and ratio of liquid to solid of $27 \mathrm{~mL} / \mathrm{g}$. The efficiency of UAAE on PSMPI was determined. The result showed that the experimental value $(80.76 \mathrm{~g} / 100 \mathrm{~g})$ of the yield of PSMPI was reasonably close to the predicted one $(81.86 \mathrm{~g} / 100 \mathrm{~g})$. This suggested that there was a high fit degree between experimental value and the predicted value from the regression model. Thus, it suggested that the equation of the response surface can be utilized effectively to predict the extraction condition of the PSMPI.

Key words: Box-behnken, ultrasound-assisted alkaline extraction, pumpkin seed meal protein isolate, optimize model.

Introduction. Protein is not only a necessary nutrient for the development and maintenance of human health, but also plays an important role in the physicochemical properties and structural basis of food [1, p. 30]. At present, animal protein is still an important source of dietary protein to most people. According to the report, the world demand for animal-derived proteins is supposed to double by 2050 [2, p. 94]. However, the production of animal proteins gives a great pressure on the environment. Besides, the popularity of vegetarianism has increased greatly over the past few years on account of growing concerns about the environment, animal welfare, and health. Thus, the utilization of plant protein sources (like oilseeds, cereals and legumes) as replacers for

\footnotetext{
${ }^{1}$ This work was financially supported by the authors wish to thank the financial support provided by the Special Fund for Science and Technology Base and Talent of Guangxi (GKAD17195088) for the research work.
}

animal proteins is thought to be a good way to meet the need for food proteins.

An analysis of the latest research and publications. The most commonly used method to extract proteins from plant protein sources is alkaline solution and acid precipitation [3, p. 1843]. However, due to the long extraction process, it will lead to protein denaturation. The reason is that the stability of secondary, tertiary, or quaternary structures changes, as well as the possible adverse secondary reactions and potential toxicity, which may lead to aggregation, solidification, reduced solubility, and loss of functional properties of proteins, such as gelation and emulsification [4, p. 703].

Enzymatic extraction is another widely used technique to isolate protein. The enzyme-assisted extraction of proteins could damage the cell walls integrity due to the degradation of the major components of 
plant cell walls and fiber, including cellulose, hemicellulose, and/or pectin caused by enzymatic action, as well as the improvement in protein solubility as a result of partial hydrolysis by different proteases. The increased degradation of cell walls could enhance the protein release into the solvent. However, this method involves high energy consumption, harmful chemicals and high labor cost [5, p. 206].

Recently, as environmentally friendly techniques, the application of microwave-assisted and ultrasound-assisted extraction attracts considerable attention. The microwave power of MAE provides more uniform heating, producing a strong pressure on the plant cell walls, as a result, the desirable components could be broken and be dissolved in the solvent. The primary advantages of microwave are easy to handle, less solvent use, less waste generation, high extraction speed [6, p. 4667]. Recent studies have shown that some functional properties (water and nitrogen solubility index and foam stability) of proteins may decrease while some functional properties (fat absorption index, water absorption index, foam activity, emulsifying activity, and in vitro protein digestibility) will also be improved after microwave treatment [7, p. 543].

Ultrasound technology makes use of acoustic cavitation to disrupt plant cells and tissues and improve mass transfer during the extraction process. The application of ultrasound to assist extraction has the advantages of easy handling and safety, because it is carried out at atmospheric pressure and ambient temperature, uses an appropriate amount of solvent, is reusable and requires relatively short processing time $[8$, p. $50 ; 9$, p. 813]. It was reported that ultrasound-assisted extraction significantly increased protein yield from rice bran, soy bean, perilla seed and pumpkin seed. However, high power and long time of sonication may reduce emulsification and foaming capability [2, p. 93]. Notably, according to the previous study, both of the ultrasound treatment and microwave treatment could decreasing the allergenicity of soybean protein isolate due to the alteration of secondary structure of proteins [10, p. 410; 11, p. 604].

Pumpkin seeds are a by-product in the utilization of pumpkin, which protein content ranges from $24.5-36 \%[12,701]$. The defatted pumpkin seed meal was obtained after cold-pressing oil extraction from pumpkin seeds and is considered to be a potential source of proteins for human consumption [13, p. 470]. The main constituents of pumpkin seed proteins are: albumin (water-soluble), globulin (salt-soluble), glutenin (alkali-soluble) and proline (alcohol-soluble) [14, p. 591]. It has been demonstrated that the essential amino acids content of globulin, glutelin and prolamin in pumpkin seed meet the minimum FAO / WHO / UNU needs for preschool children, except threonine and lysin [15, p. 7715]. The pumpkin seed meal could be transferred to additional value products such as protein concentrate or isolate and applied in food processing as dietary supplements and functional foods.

The purpose and the objectives of the study. The main goal of the investigation is - to optimize the ultrasound-assisted alkaline extraction (UAAE) conditions of pumpkin seed meal protein isolate (PSMPI) by response surface methodology.

Tasks to be solved in the research process:

1. Obtain a quadratic model of the extraction yield of pumpkin seed meal protein isolate (PSMPI).

2. Analyze how extraction factors, such as ultrasound power, ultrasound time, and the ratio of liquid to solid, affect the extraction yield of PSMPI by analyzing the response surface contour plots.

3 . Experimentally determine the optimal conditions for the extraction of PSMPI.

Methods. In this study, defatted pumpkin seed meal and water were mixed in a $250 \mathrm{~mL}$ beaker. The $\mathrm{pH}$ of the mixture was adjusted and maintained to 10.5 by using a $2 \mathrm{~N} \mathrm{NaOH}$ solution. The ultrasonic experiments were performed at $25 \mathrm{MHz}$ using an Ultrasonic microwave synergistic extraction apparatus (XH-300B, Beijing xianghu, Beijing, China) with an ultrasonic unit (maximal power of $1500 \mathrm{~W}$ ). On the basis of previous experiments, the extraction process was performed at different ultrasonic power $\left(\mathrm{X}_{1}: 400-500 \mathrm{~W}\right)$, ultrasonic time $\left(\mathrm{X}_{2}: 15-25 \mathrm{~min}\right)$ and ratio of liquid to solid $\left(\mathrm{X}_{3}: 20\right.$ to $30 \mathrm{mg} / \mathrm{L}$ ) (Table 1).

After extraction, the product was centrifuged at $4,000 \times \mathrm{g}$ for $20 \mathrm{~min}$, and the resulting supernatant was filtered to further remove the undissolved components. The filtrate was acidified to $\mathrm{pH} 4.5$ with $2 \mathrm{~N} \mathrm{HC1}$, then centrifuged at $4,000 \times \mathrm{g}$ for $15 \mathrm{~min}$. The pellet was recovered, washed with distilled water and centrifuged again as above. The pellet was freeze dried and used for protein determination and the yield calculation of PSMPI.

The experiment was conducted with triplicate samples. Analysis of variance was utilized to test for significant differences between independent variables $(\mathrm{P}<0.05)$. The statistical analysis was performed with Design expert 10 software (Stat-Ease, Minneapolis, MN, USA) and Microsoft Office Excel 2016 (Microsoft Corporation, USA), respectively.

Results and discussion. The independent variables $\mathrm{X}_{1}$ (ultrasonic power), $\mathrm{X}_{2}$ (ultrasonic time) and $\mathrm{X}_{3}$ (ratio of liquid to solid), at three variation levels studied were showed in Table 1. 
Independent variables and levels for Box Behnken design

\begin{tabular}{|c|c|c|c|c|}
\hline \multirow{2}{*}{ Independent variables } & \multirow{2}{*}{ Symbol } & \multicolumn{3}{|c|}{ Level } \\
\cline { 3 - 5 } & & $\mathbf{- 1}$ & $\mathbf{0}$ & $\mathbf{1}$ \\
\hline Ultrasonic power (W) & $\mathrm{X}_{1}$ & 400 & 450 & 500 \\
\hline Ultrasonic time (min) & $\mathrm{X}_{2}$ & 15 & 20 & 25 \\
\hline $\begin{array}{c}\text { Ratio of liquid to solid } \\
\text { (mg/L) }\end{array}$ & $\mathrm{X}_{3}$ & 20 & 25 & 30 \\
\hline
\end{tabular}

The yield of pumpkin seed meal protein isolate (PSMPI) under the Box-Behnken experimental design was presented in Table 2 . The quadratic model applied in the response surface was as follows:

$$
\mathrm{Y}=\begin{aligned}
& 80.93+1.63 X_{1}+3.04 X_{2}+1.27 X_{3}-4.46 X_{1}^{2}- \\
& -3.38 X_{2}^{2}-1.27 X_{3}^{2}-0.042 X_{1} X_{2}-1.52 X_{1} X_{3}-0.74 X_{2} X_{3}
\end{aligned}
$$

According to the results of analysis of variance (ANOVA) (Table 3), the ultrasonic power, ultrasonic time, and ratio of liquid to solid all had significant positive linear effects. The coefficient of determination $\left(\mathrm{R}^{2}\right)$ was 0.9681 , which indicated a good model fit for $96.81 \%$ of the total variation can be explained by the model. The value of the adjusted determination coefficient $\left(\mathrm{R}_{\mathrm{Adj}}{ }^{2}\right)$ was 0.9107 , which also suggested that the model was significant. The values of coefficient variation $(\mathrm{CV})$ was 1.61 , indicating a very high degree of precision and a good reliability of the experimental values.

The effects of ultrasonic power $\left(\mathrm{X}_{1}\right)$ and ultrasonic time $\left(\mathrm{X}_{2}\right)$ on the extraction yield of PSMPI were presented in Fig. 1a, b, while ratio of liquid to solid was settled at its middle level $(25 \mathrm{mg} / \mathrm{L})$. As the response surface and its corresponding counter plot shows, the extraction yield of PSMPI increased slowly as the ultrasonic time increased when ultrasonic power at a low level. With the increase in ultrasonic power, the yield of PSMPI improved from about $75 \mathrm{~g} / 100 \mathrm{~g}$ to $80 \mathrm{~g} / 100 \mathrm{~g}$ at a high level of ultrasonic time. However, the yield of PSMPI increased only from about $71 \mathrm{~g} / 100 \mathrm{~g}$ to $75 \mathrm{~g} / 100 \mathrm{~g}$ at a low level of ultrasonic time. It indicated that the increase of ultrasonic power and ultrasonic time in the test range was beneficial for the extraction of PSMPI.

The response surface and its corresponding counter plot which showed the effects of ultrasonic power $\left(\mathrm{X}_{1}\right)$ and ratio of liquid to solid $\left(\mathrm{X}_{3}\right)$ on the yield of PSMPI were presented in Fig. 1c, d, while maintaining ultrasonic time $\left(\mathrm{X}_{2}\right)$ at a middle level of $20 \mathrm{~min}$. At the middle level of ultrasonic power and ratio of liquid to solid, the maximum extraction yield of PSMPI was achieved, further increasing in ultrasonic power and ratio of liquid to solid would not add into increase in the extraction yield of PSMPI.

The effects of ultrasonic time $\left(\mathrm{X}_{2}\right)$ and ratio of liquid to solid $\left(\mathrm{X}_{3}\right)$ on the yield of PSMPI were showed in Fig. 1e, $\mathrm{f}$, while keeping the ultrasonic power $\left(\mathrm{X}_{1}\right)$ at a middle level $(450 \mathrm{~W})$. The yield of PSMPI showed a considerable increase as the increase in ratio of liquid to solid at a high level of ultrasonic time. However, when ultrasonic time is at a low level, the effect of

Table 2

Box-Behnken design arrangement, responses for protein yield of ultrasound-assisted alkaline extraction on pumpkin seed meal protein isolate (PSMPI)

\begin{tabular}{|c|c|c|c|c|c|}
\hline Run & $\begin{array}{c}\mathbf{X}_{1}: \text { Ultrasonic } \\
\text { power (W) }\end{array}$ & $\begin{array}{c}\mathbf{X}_{2}: \text { Ultrasonic } \\
\text { time (min) }\end{array}$ & $\begin{array}{c}\mathbf{X}_{\mathbf{3}}: \\
\text { Ratio of liquid to } \\
\text { solid (mg/L) }\end{array}$ & Yield (g/100 g) & $\begin{array}{c}\text { Predicted } \\
\text { Value } \\
(\mathbf{g} / \mathbf{1 0 0} \mathbf{g})\end{array}$ \\
\hline 1. & 1 & 1 & 0 & 77.79 & 77.72 \\
\hline 2. & 1 & 0 & -1 & 78.13 & 77.09 \\
\hline 3. & 0 & 0 & 0 & 80.56 & 80.93 \\
\hline 4. & 1 & -1 & 0 & 70.59 & 71.72 \\
\hline 5. & 1 & 0 & 1 & 76.59 & 76.57 \\
\hline 6. & -1 & -1 & 0 & 68.31 & 68.38 \\
\hline 7. & 0 & 1 & 1 & 79.77 & 79.86 \\
\hline 8. & -1 & 0 & 1 & 75.32 & 76.36 \\
\hline 9. & -1 & 0 & -1 & 70.77 & 70.79 \\
\hline 10. & 0 & -1 & -1 & 71.34 & 71.25 \\
\hline 11. & -1 & 1 & 0 & 75.68 & 74.55 \\
\hline 12. & 0 & 1 & -1 & 77.68 & 78.80 \\
\hline 13. & 0 & -1 & 1 & 76.37 & 75.25 \\
\hline 14. & 0 & 0 & 0 & 80.95 & 80.93 \\
\hline 15. & 0 & 0 & 0 & 81.29 & 80.93 \\
\hline
\end{tabular}


ratio of liquid to solid on the yield of PSMPI was not significant.

The optimum extraction conditions depended on ultrasonic power $\left(\mathrm{X}_{1}\right)$, ultrasonic time $\left(\mathrm{X}_{2}\right)$ and ratio of liquid to solid $\left(\mathrm{X}_{3}\right)$, and were obtained by response surface methodology (RSM). To validate the model, PSMPI were extracted under optimal UAAE conditions and its efficiency was determined. The result showed that the experimental value $(80.76 \mathrm{~g} / 100 \mathrm{~g})$ of the yield of PSMPI was reasonably close to the predicted one $(81.86 \mathrm{~g} / 100 \mathrm{~g})$. This suggested that there was a high fit degree between experimental value and the predicted value from the regression model. Hence, the response surface modeling can be utilized effectively to predict the extraction condition of the PSMPI.

Conclusions. In the present study, ultrasound-assisted alkaline extraction (UAAE) of pumpkin seed meal protein isolate (PSMPI) was proposed. Since many factors, like ultrasonic power, ultrasonic time and ratio of liquid to solid effect the yield of PSMPI, the response surface method was conducted to optimize the extraction conditions by three factors at three level Box-Behnken design. Response surface and contour plots suggested that the optimum condition for extracting PSMPI is at $456 \mathrm{~W}$ of ultrasonic power, 22 minutes of ultrasonic time and $27 \mathrm{mg} / \mathrm{L}$ for ratio of liquid to solid with a maximum protein yield of $81.86 \mathrm{~g} / 100 \mathrm{~g}$. These results will contribute to the information of the productivity of the PSMPI by the method of UAAE.
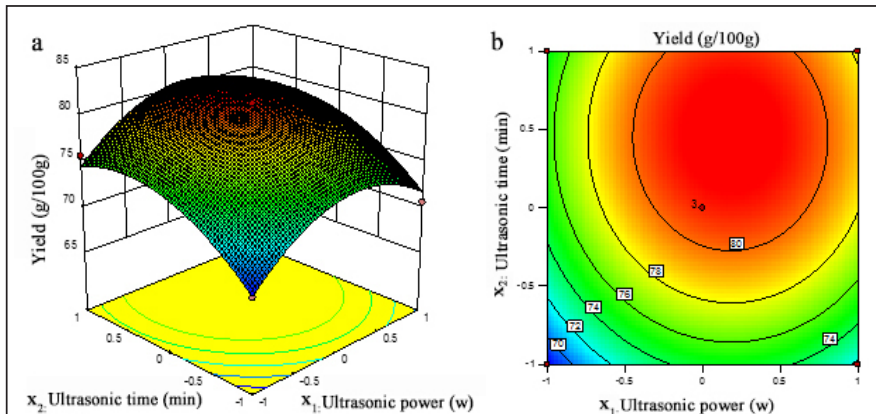

$x_{1}$ Ultrasonic power (w)
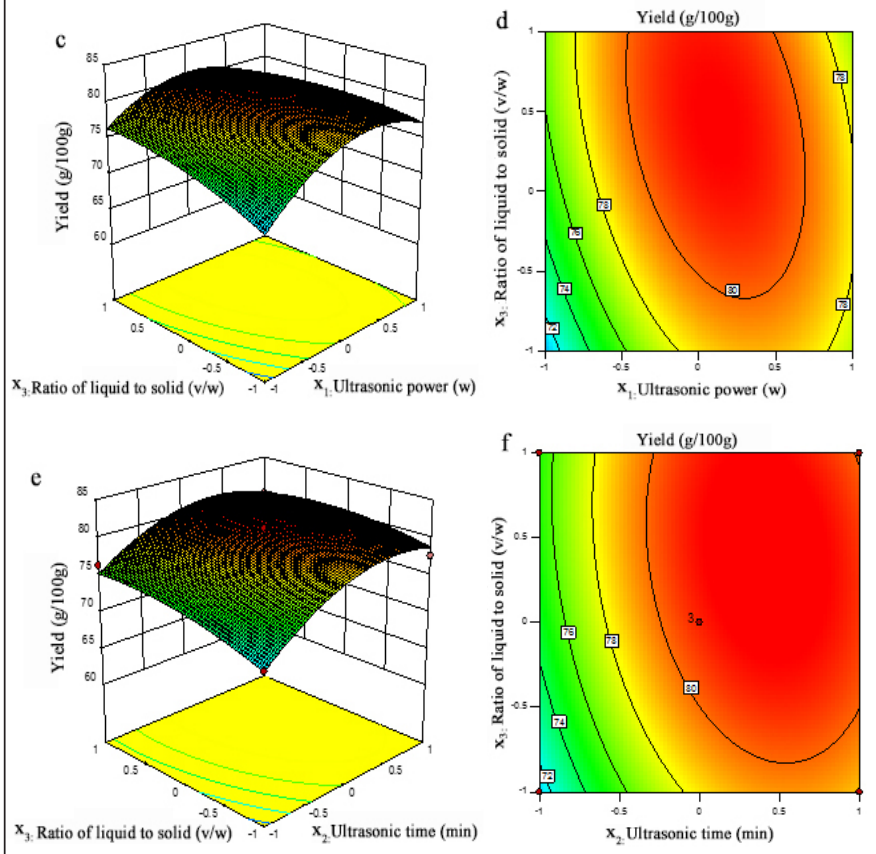

Fig. 1. Response surfaces (a, c and e) and contour plots (b, $d$ and $f$ ) showing effects of extraction variables $\left(X_{1}\right.$, ultrasonic power; $\mathbf{X}_{2}$, ultrasonic time; $\mathbf{X}_{3}$, ratio of liquid to solid) on the ultrasound-assisted alkaline extraction (UAAE) yield of pumpkin seed meal protein isolate (PSMPI)

Table 3

Analysis of the variance (ANOVA) of the quadratic model

\begin{tabular}{|c|c|c|c|c|c|}
\hline Source & Sum of Squares & df & $\begin{array}{c}\text { Mean } \\
\text { Square }\end{array}$ & F-Value & $\begin{array}{c}\text { p-value } \\
\text { Prob }>\text { F }\end{array}$ \\
\hline Model & 228.95 & 9 & 25.44 & 16.87 & 0.0031 \\
\hline $\mathrm{A}_{1}$ & 21.19 & 1 & 21.19 & 14.05 & 0.0133 \\
\hline $\mathrm{A}_{2}$ & 73.87 & 1 & 73.87 & 48.98 & 0.0009 \\
\hline $\mathrm{A}_{3}$ & 12.83 & 1 & 12.83 & 8.50 & 0.0332 \\
\hline $\mathrm{A}_{12}$ & 0.0072 & 1 & 0.0072 & 0.0048 & 0.9475 \\
\hline $\mathrm{A}_{13}$ & 9.27 & 1 & 9.27 & 6.15 & 0.0559 \\
\hline $\mathrm{A}_{23}$ & 2.16 & 1 & 2.16 & 1.43 & 0.2850 \\
\hline $\mathrm{A}_{11}$ & 73.58 & 1 & 73.58 & 48.78 & 0.0009 \\
\hline $\mathrm{A}_{22}$ & 42.10 & 1 & 42.10 & 27.91 & 0.0032 \\
\hline $\mathrm{A}_{33}$ & 5.92 & 1 & 5.92 & 3.93 & 0.1043 \\
\hline Residual & 7.54 & 5 & 1.51 & & \\
\hline Lack of Fit & 7.27 & 3 & 2.42 & 18.17 & 0.0526 \\
\hline Pure Error & 0.27 & 2 & 0.13 & & \\
\hline Cor Total & 236.49 & 14 & & \\
\hline
\end{tabular}




\section{References:}

1. Day L. Proteins from land plants - Potential resources for human nutrition and food security. Trends in Food Science and Technology. 2013. V. 32. № 1. P. 25-42.

2. Pojić M., Mišan A., Tiwari B. Eco-innovative technologies for extraction of proteins for human consumption from renewable protein sources of plant origin. Trends in Food Science and Technology. 2018. № 75. P. 93-104.

3. Chittapalo T., Noomhorm A. Ultrasonic assisted alkali extraction of protein from defatted rice bran and properties of the protein concentrates. International journal of food science and technology, 2009. V. 44. № 9. P. $1843-1849$.

4. Haque M.A., Aldred P., Chen J., Barrow C.J., Adhikari B. Comparative study of denaturation of whey protein isolate (WPI) in convective air drying and isothermal heat treatment processes. Food Chemistry. 2013. V. 141. № 2. P. 702-711.

5. Watanabe M., Maeda I., Koyama M., Nakamura K., Sasano K. Simultaneous recovery and purification of rice protein and phosphorus compounds from full-fat and defatted rice bran with organic solvent-free process. Journal Bioscience and Bioengineering. 2015. V. 119. № 2. P. 206-211.

6. Kadam S.U., Tiwari B.K., O'Donnell C.P. Application of novel extraction technologies for bioactives from marine algae. Journal of Agricultural and Food Chemistry. 2013. V. 61. № 20. P. 4667-4675.

7. Ochoa-Rivas A., Nava-Valdez Y., Serna-Saldívar S. O., Chuck-Hernández C. Microwave and ultrasound to enhance protein extraction from peanut flour under alkaline conditions: Effects in yield and functional properties of protein isolates. Food and Bioprocess Technology. 2017. № 10. P. 543-555.

8. Bendicho C, De La Calle I., Pena F., Costas M., Cabaleiro N., Lavilla I. Ultrasound-assisted pretreatment of solid samples in the context of green analytical chemistry. Trends in Analytical Chemistry. 2012. № 31. P. 50-60.

9. Chemat F., Khan M.K. Applications of ultrasound in food technology: Processing, preservation and extraction. Ultrasonics Sonochemistry. 2011. V. 18. № 4. P. 813-835.

10. Yang X., Li Y., Li S., Oladejo A.O., Wang Y., Huang S. Effects of low power density multi-frequency ultrasound pretreatment on the enzymolysis and the structure characterization of defatted wheat germ protein. Food Engineering Reviews. 2017. № 38. P. 410-420.

11. Li H., Zhu K., Zhou H., Peng W., Guo X. Comparative study of four physical approaches about allergenicity of soybean protein isolate for infant formula. Food and Agricultural Immunology. 2016. V. 27. № 5. P. 604-623.

12. Quanhong L., Caili F. Application of response surface methodology for extraction optimization of germinant pumpkin seeds protein. Food Chemistry. 2005. V. 92. № 4. P. 701-706.

13. Popović S., Peričin D., Vaštag Ž., Popović L., Lazić V. Evaluation of edible film-forming ability of pumpkin oil cake; effect of $\mathrm{pH}$ and temperature. Food Hydrocolloids. 2011. V. 25. № 3. P. 470-476.

14. Peričin D., Radulovic' L., Trivić S., Dimic' E. Evaluation of solubility of pumpkin seed globulins by response surface method. Journal of Food Engineering. 2008. V. 84. № 4. P. 591-594.

15. Rezig L., Chibani F., Chouaibi M., Dalgalarrondo M., Hessini K., Gueguen J., Hamdi S. Pumpkin (Cucurbita maxima) seed proteins: sequential extraction processing and fraction characterization. Jouranl of Agricultural and Food Chemistry. 2013. V. 61. № 32. P. 7715-7721.

\section{Геліх А.О., Гао Д., ДУан З. ОПТИМІЗАЦІЯ УЛЬТРАЗВУКОВОЇ ПІДТРИМКИ ЛУЖНОЇ ЕКСТРАКЦІЇ ІЗОЛЯТІВ БІЛКА БОРОШНА 3 ГАРБУЗОВОГО НАСІННЯ ЗА МЕТОДОЛОГІЄЮ ПОВЕРХНІ ВІДГУКУ}

В якості альтернативи тваринним білкам ізолят білка борошна з насіння гарбуза (ІББНГ) може застосовуватися в харчовій промисловості в якості харчових добавок і функиіональних харчових продуктів. Звичайний процес екстракиії білка є лужним розчином $і$ кислотними осадами, які перетворюють тривалий час. Ультразвуковий метод є екологічно чистим методом, який можна використовувати для підвищення ефективності екстракиії білка.

В иьому дослідженні був розроблений метод ультразвукової лужної екстракиї̈ (УЛЕ) білка борошна з насіння гарбуза. Методологія поверхні відгуку (МПВ) була використана для оптимізачії умов УЛЕ (потужність ультразвуку, час ультразвуку і співвідношення рідини до твердої речовини) шляхом реалізачї трьохфакторної трирівневої конструкиії Боксу-Бенкена. Квадратичне поліноміальне рівняння було отримано за допомогою поліноміального регресійного аналізу експериментальних даних і відповідних статистичних методів. Вплив взаємодії незалежних змінних на вихід екстракиї ІББНГ було проілюстровано за допомогою поверхонь відгуку та контрольних графіків.

Крім того, иляхом вирішення рівняння регресії й аналізу контурних графіків поверхні відгуку були отримані певні оптимальні умови екстракиї ІББНГ, які мали потужнність ультразвуку 456 Вт, час ультразвуку 22 хв і співвіднотення рідини до твердої речовини 27 мл/м. Була визначена ефективність УЛЕ по виходу ІББНГ. Результат показав, що експериментальне значення (80,76 2/100 г) виходу ІББНГ було досить близько до прогнозованого (81,86 г/100 г). Це говорить про те, що існує високий ступінь відповідності між експериментальним значенням і прогнозним значенням із регресійній моделі. Було доведено, що рівняння поверхні відгуку може ефективно використовуватися для прогнозування умови вилучення ІББНГ.

Ключові слова: Бокс-Бенкен, ультразвукова лужна екстракиія, білковий ізолят борошна з насіння гарбуза, оптимізована модель. 